\title{
Rehyd Development and Installation Report
}

Robert L. Schuch, Haskell N. Woodall

Prepared by Sandia Laboratories, Albuquerque, New Mexico 87115 and Livermore, California 94550 for the United States Department

of Energy under Contract AT(29-1)-789

Printed December 1977 


\section{DISCLAIMER}

This report was prepared as an account of work sponsored by an agency of the United States Government. Neither the United States Government nor any agency Thereof, nor any of their employees, makes any warranty, express or implied, or assumes any legal liability or responsibility for the accuracy, completeness, or usefulness of any information, apparatus, product, or process disclosed, or represents that its use would not infringe privately owned rights. Reference herein to any specific commercial product, process, or service by trade name, trademark, manufacturer, or otherwise does not necessarily constitute or imply its endorsement, recommendation, or favoring by the United States Government or any agency thereof. The views and opinions of authors expressed herein do not necessarily state or reflect those of the United States Government or any agency thereof. 


\section{DISCLAIMER}

Portions of this document may be illegible in electronic image products. Images are produced from the best available original document. 
Issued by Sandia Laboratories, operated for the United States Department of Energy by Sandia Corporation.

\section{NOTICE}

This report was prepared as an account of work sponsored by the United States Government. Neither the United States nor the United States Department of Energy, nor any of their employees, nor any of their contractors, subcontractors, or their employees, makes any warranty, express or implied, or assumes any legal liability or responsibility for the accuracy, completeness or usefulness of any information, apparatus, product or process disclosed, or represents that its use would not infringe privately owned rights.

Printed in the United States of America

Available from

National Technical Information Service

U. S. Department of Commerce

5285 Port Royal Road

Springfield, VA 22161

Price: Printed Copy $\$ 4.00$; Microfiche $\$ 3.00$ 


\section{PAGES 1 to 2 WERE INTENTIONALLY LEFT BLANK}


SAND77-0599.

Unlimited Release

Printed December 1977

REHYD. DEVELOPMENT AND INSTALLATION REPORT

\author{
Robert. L. Schuch \\ Haskell N. Woodall \\ Beam Source Applications Division 5232 \\ Sandia Laboratories \\ Albuquerque, NM 87115
}

\begin{abstract}
Rehyd, a low-impedance, HYDRA-type, water transmission line for bremsstrahlung exposures, has been installed on the north side of the REBA facility. Rehyd produces $300-\mathrm{kA}$ heams of $1.2-\mathrm{MeV}$ electrons with a pulse width of $170 \mathrm{~ns}$. Nominal X-ray exposure dose capabllltles of $7 \mathrm{cal} / \mathrm{g}$ and 20 $25 \mathrm{~kJ}$ have been realized thus far. This report describes specific design parameters and facility layouts including the unique features of the REBA Marx generator/Rehyd line energy-

transfer system. Diode configurations, magnetic-field applications, and output measurements are also presented.
\end{abstract}

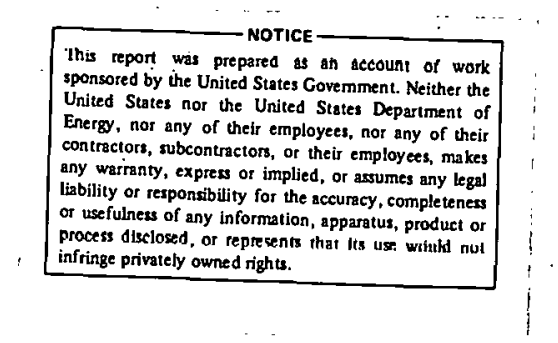




\section{ACKNOWLEDGMENT}

The authors wish to thank L. D. Posey, P. E. Bolduc, and J. A. Bloomquist for their work on the design analysis; B. J. Joseph and D. D. Craig for their work on the mechanical design; R. T. Baff for expediting fabrication; J. E. Harness and W. Simmons for their assistance in the assembly of the Rehyd facility; T. P. Lynch and J. G. Romero for machine operations; and T.i D. Gaseman for edilurial assistance. 


\section{CONTENTS}

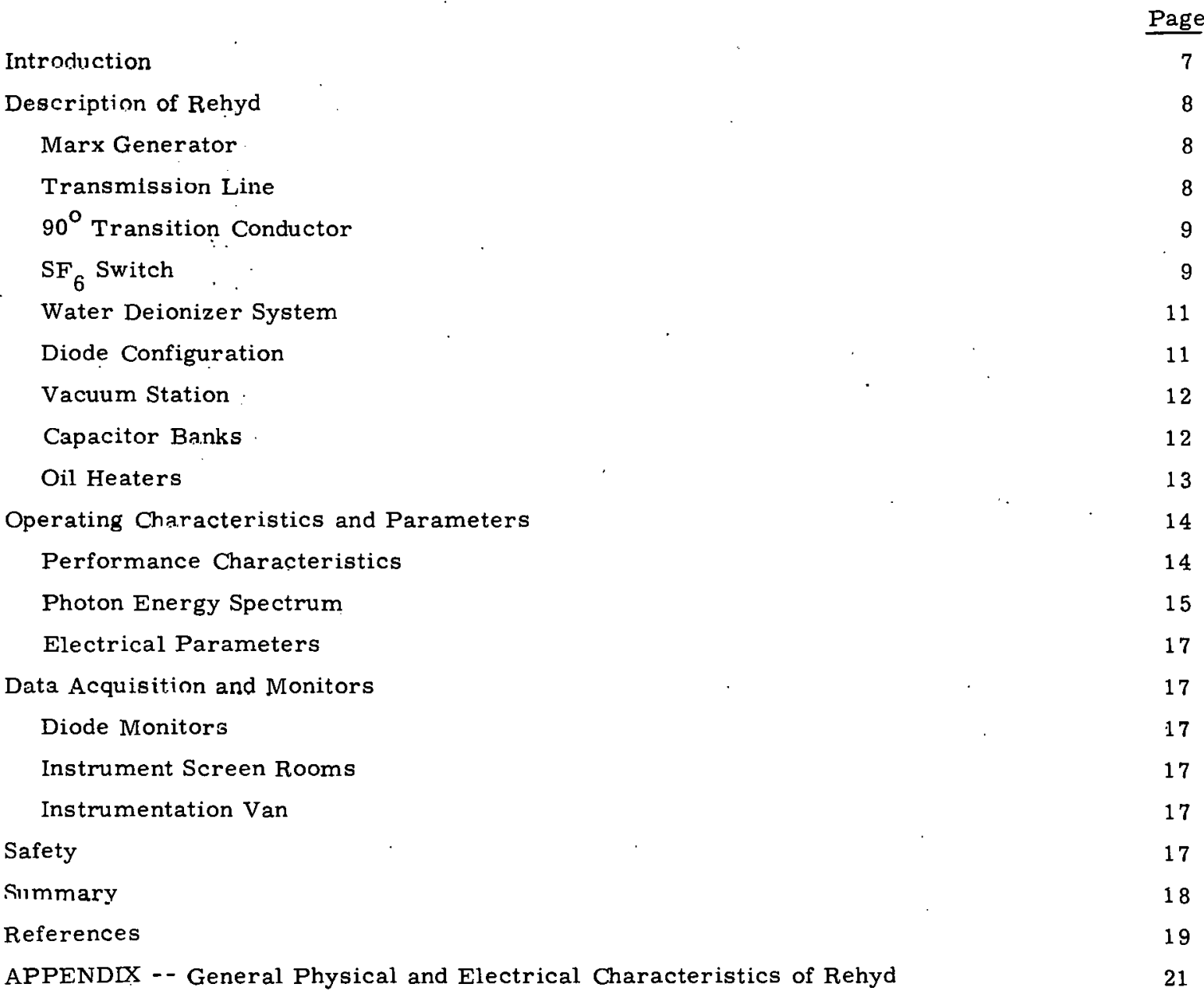

\section{ILLUSTRATIONS}

\section{Figure}

1 Cutaway Drawing of Rehyd

2 Layout of Rehyd and North Radiation Cell

3 Rehyd Transmission Line (Side View)

$490^{\circ}$ Transition Conductor (Oil Section)

5 FFEAnS Plot, $90^{\circ}$ Tranaition Conductor

6 Diode and Magnetic Compression Solenoid

7 Rehyd Vacuum System (Front View)

8 Capacitor Banks and Selector Relays 


\section{Figure}

9 Diode Mod II and Convertor Assembly with Standoff and Gap for Rehyd

10 Calculated Rehyd Photon Energy Spectrum for Shot No. 282

11 Rehyd X-Ray Spectra Along Forward-Directed Normal to Convertor for Energies Less Than $0.2 \mathrm{MeV}$

12 Rehyd X-Ray Spectra Along Forward-Directed Normal to Convertor for Energies Greater Than 0.1 MeV

\section{TAB̄LE}

\section{Table}

I Rehyd Performance Characteristics With Mod II Diọde Configuration and Advanced Convertor Assembly 


\title{
REHYD DEVELOPMENT AND INSTALLATION REPORT
}

\author{
Introduction
}

As part of the continuing development of simulation capabilities at Sandia Laboratories, ${ }^{1}$ the HYDRA accelerator ${ }^{2}$ was designed to satisfy the requirements for an X-ray radiation source. Because of the demands placed on a source of this type, it was decided to replace one of the REBA high-impedance oil Blumleins by a transmission line similar to one of the HYDRA, waterinsulated, low-impedance $(4 \Omega$ to $2 \Omega)$, pulse-forming transmission lines. Such a replacement was possible due to the similarity of characteristics between the REBA Marx generator and the HYDRA Marx generator. The HYDRA Marx has a capacity of $29.8 \mathrm{nF}$ and an inductance of 10.5 $\mu \mathrm{H}$. For the REBA Marx, the capacity of $13.1 \mathrm{nF}$ almost matches the single HYDRA line capacitance of 11. $2 \mathrm{nF}$, while the inductance is larger $(24 \mu \mathrm{H})$. The HYDRA Marx is also capable of storing $200 \mathrm{~kJ}$ of energy (100 kJ per line), whereas the energy store of the REBA Marx (95 kJ) is nearly identical to the energy store per line for HYDRA. Furthermore, because of the similar characteristics, development work done on either source is applicable to the other. The north side of the REBA facility and the experimental cell were extensively modified to accommodate a newly fabricated HYDRA line. For reference purposes and operations identification, the modified line is known as Rehyd. A cutaway drawing of the Rehyd line and the north experimental cell is shown in Figure 1.

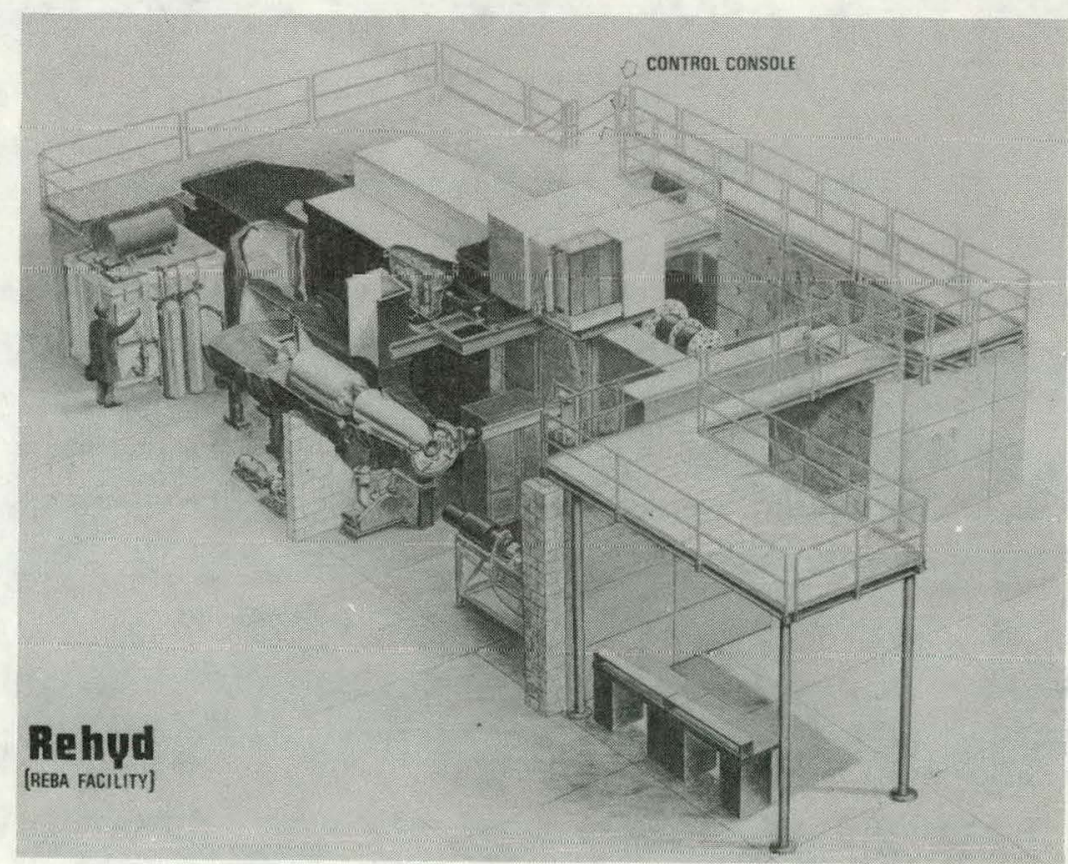

Figure 1. Cutaway Drawing of Rehyd 
Figure 2 shows the location in Building 6596 of the Rehyd facility and the north experimental cell with respect to the REBA facility. The rest of the building is occupied by the HERMES II facility.

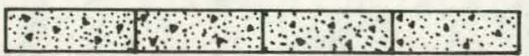

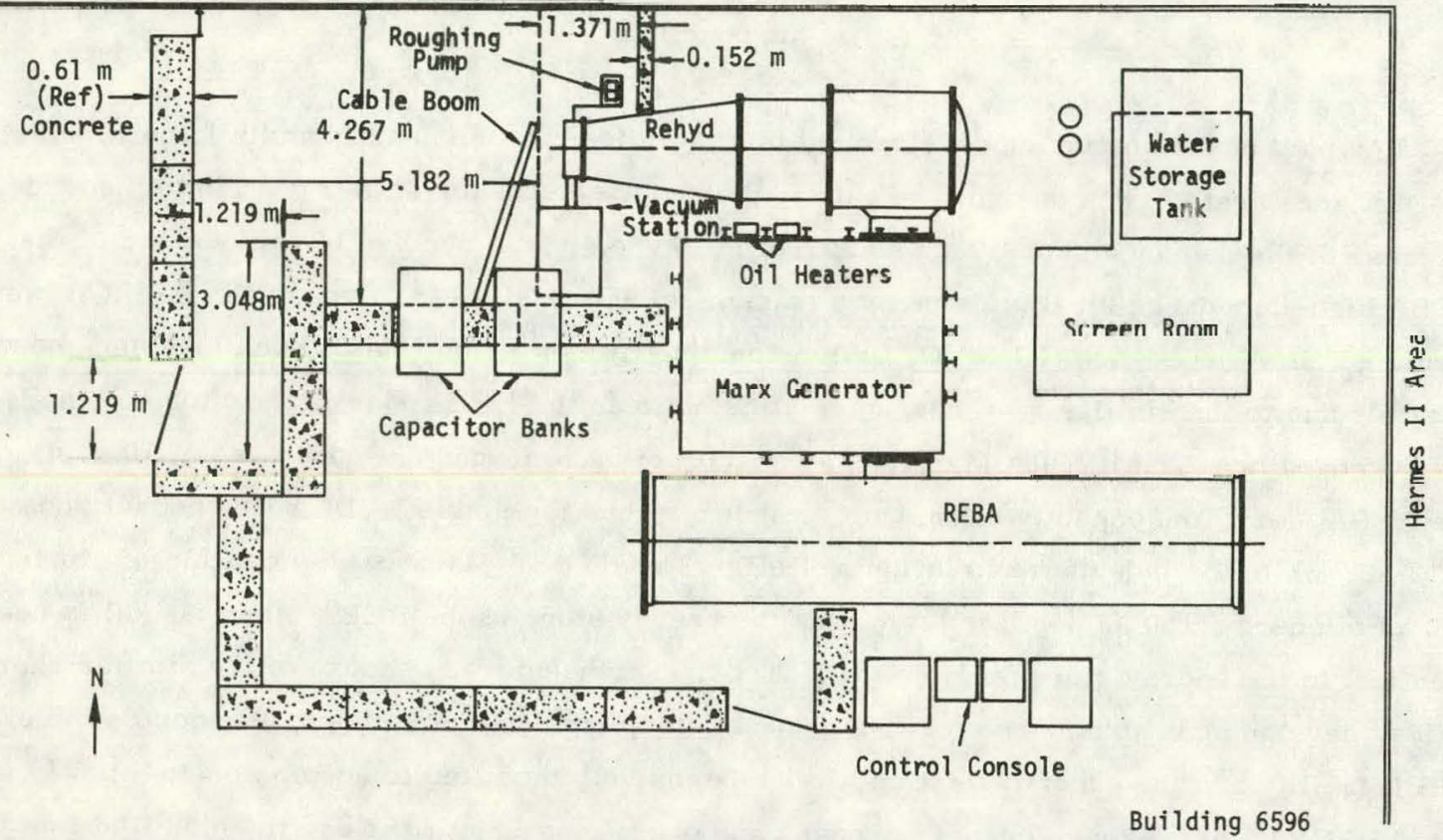

Figure 2. Layout of Rehyd and North Radiation Cell

Description of Rehyd

\section{Marx Generator}

The Rehyd line utilizes the REBA Marx generator, which stores $95 \mathrm{~kJ}$ at full voltage (100 kV) and has an output capacity of $13.1 \mathrm{nF}$. Detailed descriptions of the Marx are reported in References 3 and 4 and will not be repeated here, although the mechanical and electrical energy-switching transfer technique will be further defined in this report. No major modifications to the REBA Marx were required. An oil-heating system was installed in the oil line in order to maintain the Marx oil temperature at about $26^{\circ} \mathrm{C}$.

\section{Transmission Line}

The Rehyd water-insulated transmission line is similar in size and design to a single HYDRA line except that it runs parallel to the REBA Marx tank and is electrically connected to the Marx by an oil-insulated, $90^{\circ}$ transition (which is described below). Figure 3 shows a side view of the water-transmission-line assembly, including the outer conductor, inner conductor, SF 6 trigatron switch, lucite barriers, and diode area. Water is supplied to the transmission line through a deionizing system and can be recycled through a holding and debubbler tank. 


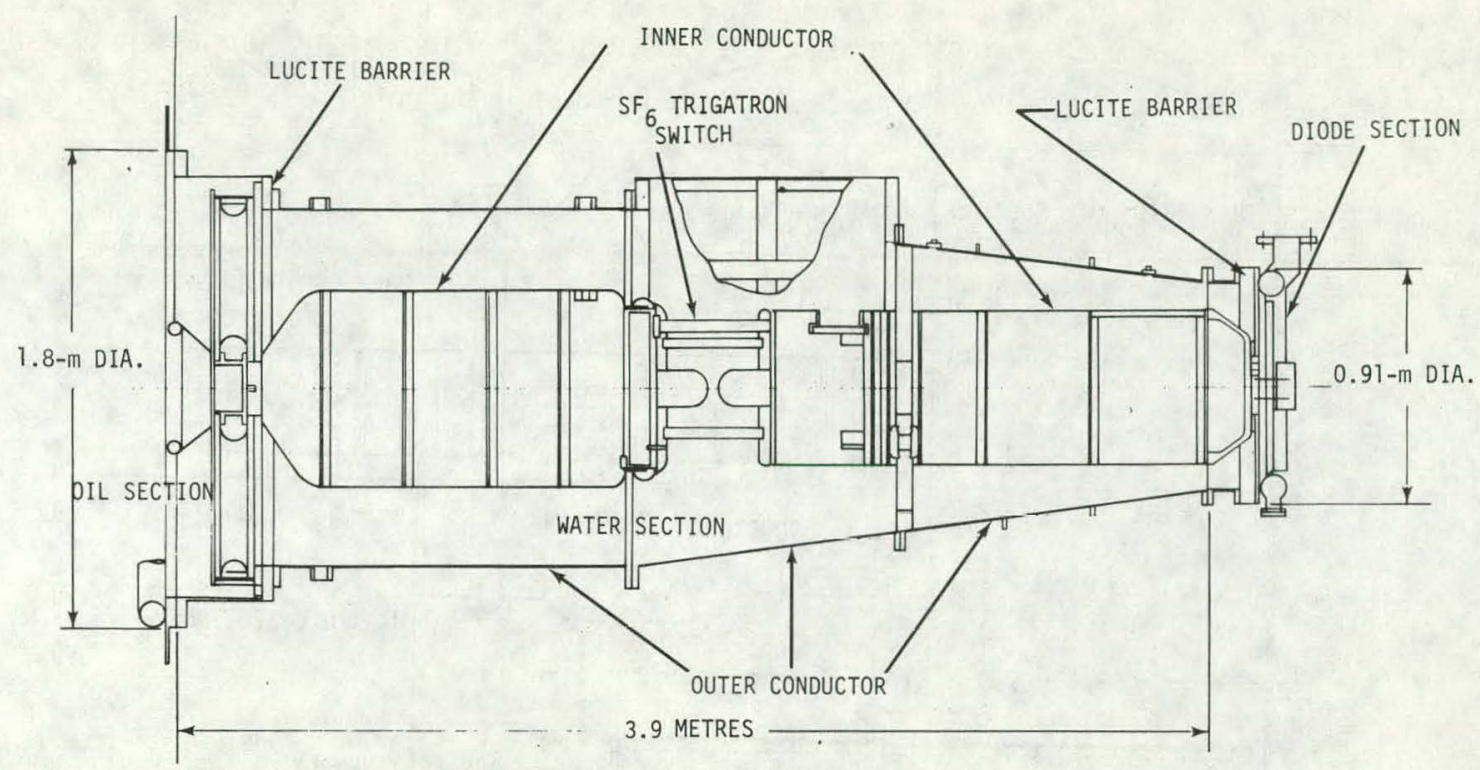

Figure 3. Rehyd Transmission Line (Side View)

$90^{\circ}$ Transition Conductor

In order to accommodate Rehyd in the REBA facility, it was necessary to design an oilbarrier conductor section that would be adaptable to the REBA Marx tank (Figure 4). A cylindrical, oil-filled tank is attached to the end of the Rehyd water-transmission line and bolted to the REBA tank. Due to the fact that an electrical shock is transmitted when the Rehyd is fired, the $90^{\circ}$ transition section was designed in two sections. As shown in Figure 4, an in-line section is fixed to the oil/water barrier, while the Marx conductor is held in contact at a $90^{\circ}$ angle by a springloaded cap. This configuration minimizes mechanical distortion of the conductor sections and relieves the strain on the lucite barriers when the machine is fired. Lucite barriers separate the transition oil section from the water line and also from the Marx tank. These barriers allow draining of each section separately without interference to the others. A computer code, FFEARS, ${ }^{5}$ was used to analyze the voltage gradients in the transition conductor in order to select an acceptable configuration; i. e., one having electric-field strengths on the high-voltage conductor of less than $0.91 \mathrm{MV} / \mathrm{cm}$, which is the breakdown level for the oil used as an insulator. Values of electric-field strength calculated for various locations along the conductor are shown in Figure 5.

$\mathrm{SF}_{6}$ Switch

The $\mathrm{SF}_{6}$ switch used on Rehyd is similar to the enlarged trigatron used on HYDRA. ${ }^{2}$ The switch electrodes were fabricated from tungsten-copper (Mallory 10w3) and mounted in a thickwalled lexan housing. As a precautionary measure to prevent the formation of air bubbles, all external parts of the switch assembly are wiped down with a wetting agent (Detergent, Cutscum, Fisher Scientific Co. ) prior to filling the transmission-line tank with water. The switch is filled with $\mathrm{SF}_{6}$ gas and is regulated between 40 and 100 psi through an external manifold and supply tanks. 


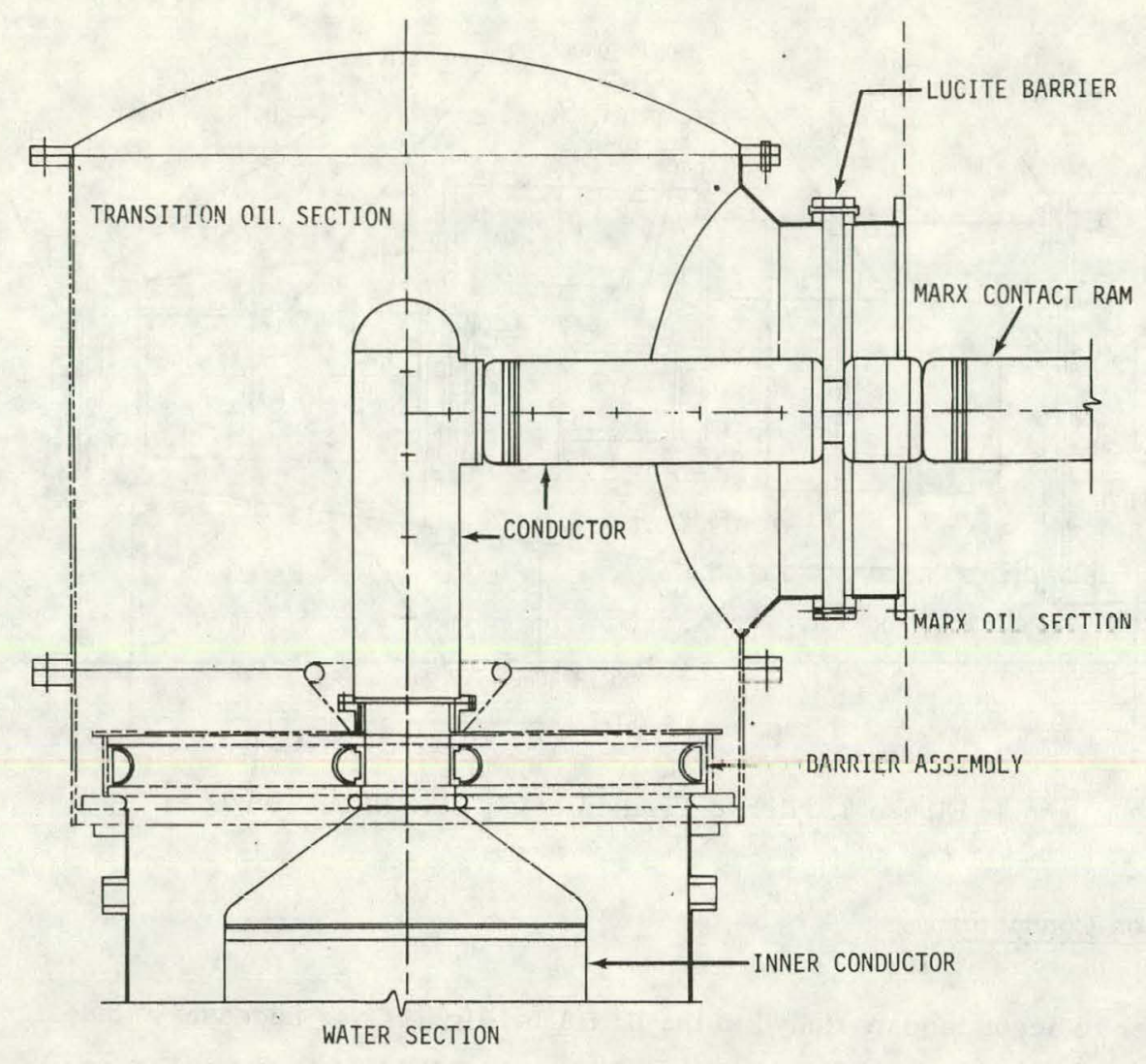

TOP VIEW

Figure 4. $90^{\circ}$ Transition Conductor (Oil Section)

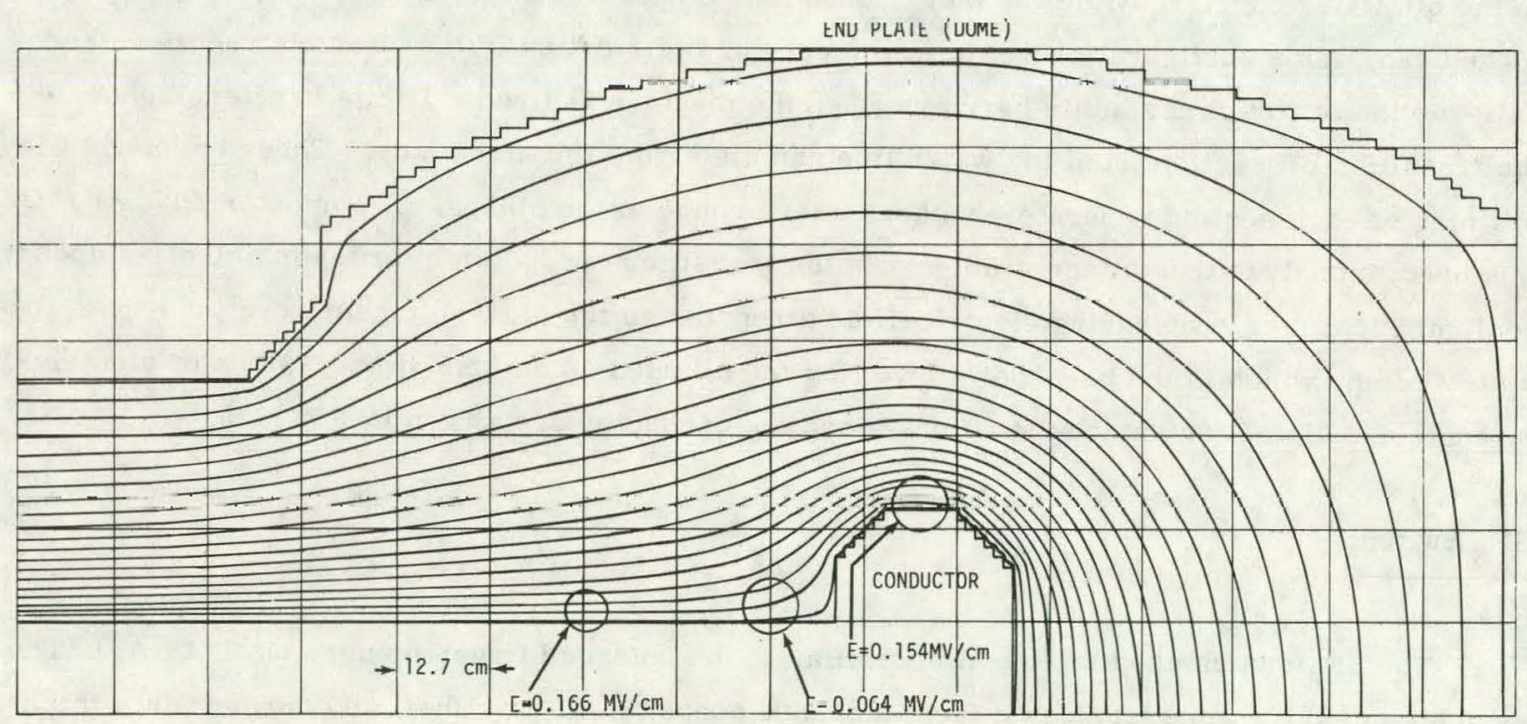

Figure 5. FFEARS Plot, $90^{\circ}$ Transition Conductor 


\section{Water Deionizer System}

In order to maintain the integrity of the low-impedance line, the water contained in the transmission line is deionized and kept at a resistance level greater than $1 \mathrm{M} \Omega / \mathrm{cm}$. Water circulates continually through the deionizer tanks, then through the storage/debubbler tank, and finally reenters at the center of the transmission line. The storage/debubbler tank must be located well above the transmission line in order to allow the circulating water to enter the line by gravity flow, thereby minimizing the number of bubbles entering the diode area.

\section{Diode Configuration}

The basic diode assembly on Rehyd is similar to that used on HYDRA ${ }^{2}$ and consists of a flat plexiglas insulator, a cylindrical cathode, an anode chamber, and a perforated torus through which the diode area can be evacuated. The electron beam is formed in the anode-cathode gap and is extracted through a thin mylar window. The beam can then be drifted externally and generally is focused into a specific target, utilizing a solenoid for magnetic-beam compression. Figure 6 sliuws llie diode, the oathode, and the snlennid.

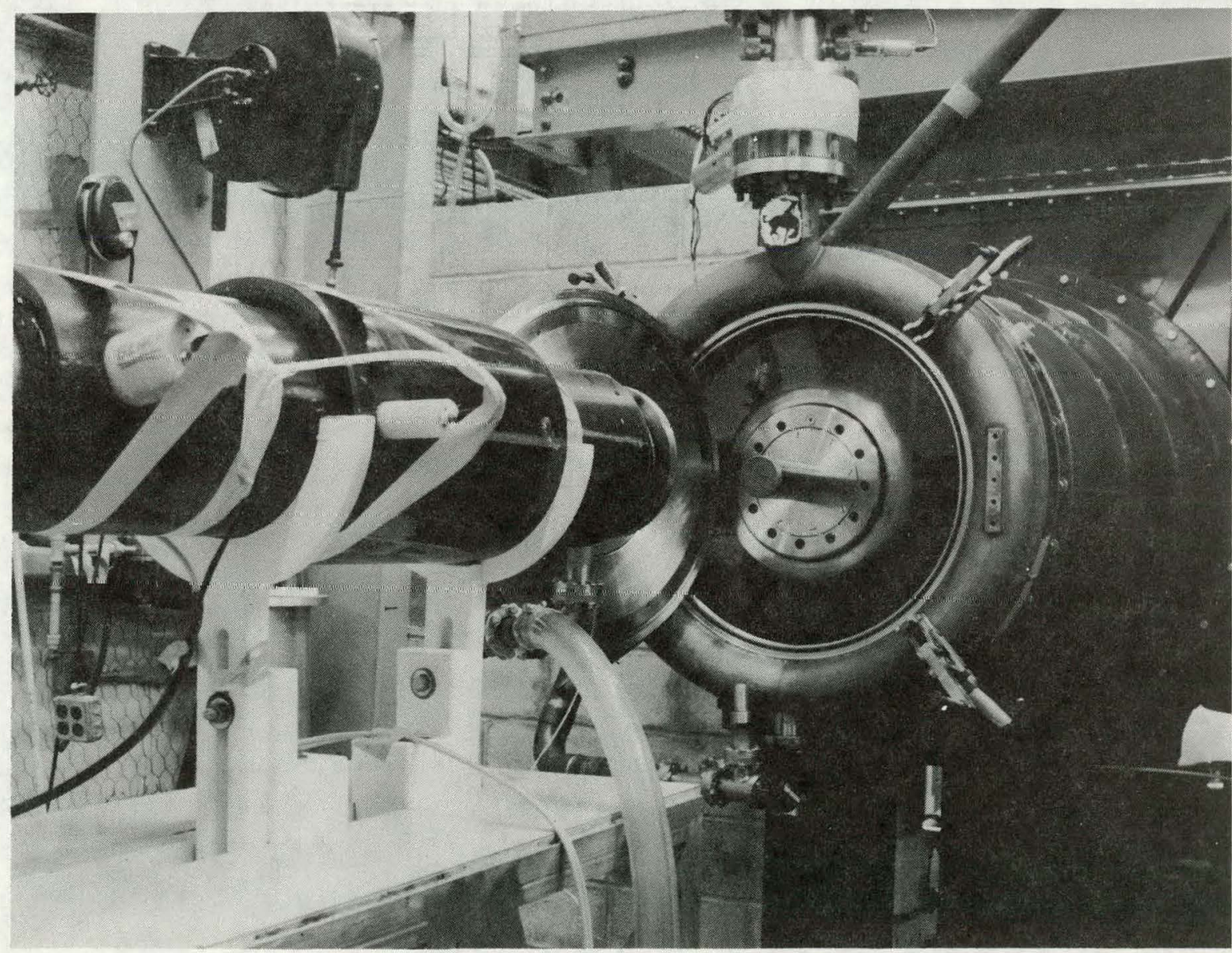

Figure 6. Diode and Magnetic Compression Solenoid 
The Rehyd diode area is evacuated through the perforated torus. Although the diode area to be evacuated is relatively small $\left(0.075 \mathrm{~m}^{3}\right)$, vaporized residues that accumulate within the torus are difficult to remove and, in turn, hinder vacuum pumping. A dual, $15-\mathrm{cm}^{3}$, diffusion-pump system (Figure 7) is mounted as close as possible to the torus, which aids in pumping down the diode and the anode drift chamber. Under ideal conditions, the system will pump down to $1 \times 10^{-5}$ torr in 20 minutes but, after a few shots, pumping time is increased to 30 to 45 minutes. An open (rather than a perforated) torus is being fabricated in an attempt to improve the diode vacuum levels and pumping times.

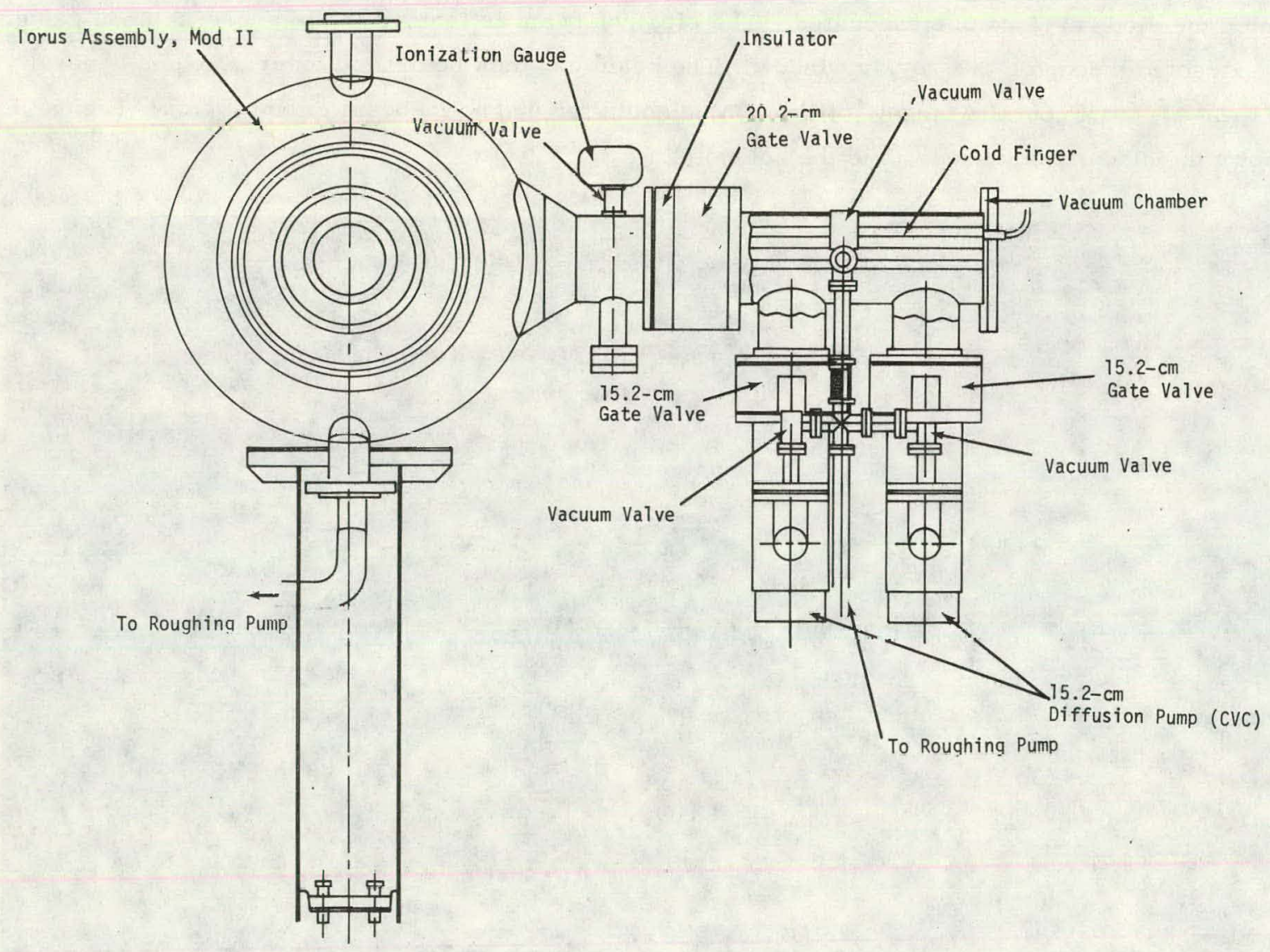

Figure 7. Rehyd Vacuum System (Front View)

\section{Capacitor Banks}

Two self-contained capacitor banks are located on top of the concrete radiation-shield wall that separates the north and south experimental cells of the REBA facility (Figure 8). These storage banks are used to energize magnetic-field coils (solenoids) which are used in conjunction with the electron-beam output of REBA and Rehyd. 


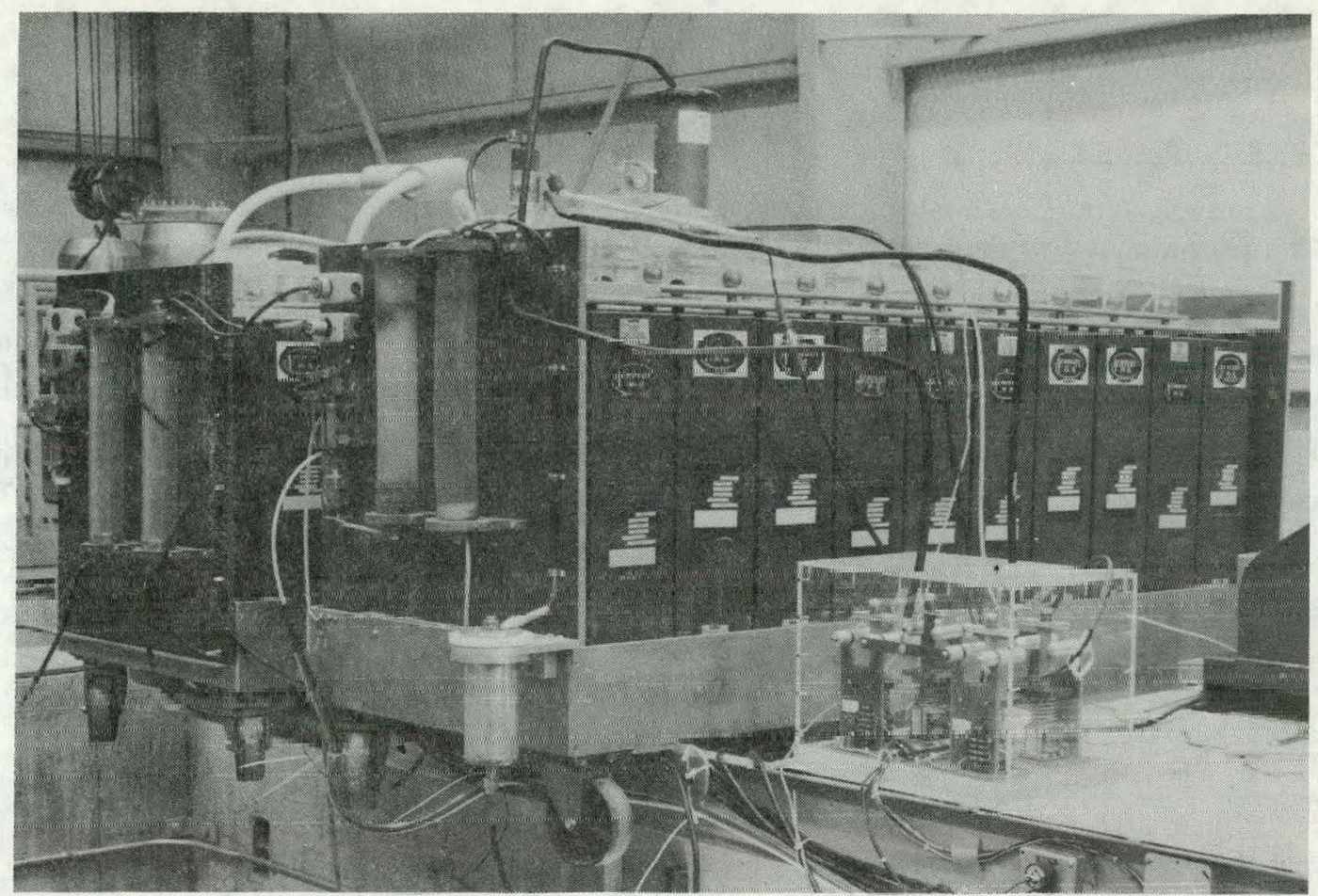

Figure 8. Capacitor Banks and Selector Relays

Each capacitor bank consists of 20 Aerovox, PC100-32, 20-kV, 2.8-kJ capacitors. The maximum storage energy with both banks connected in parallel is $112 \mathrm{~kJ}$. A selector relay is used to supply stored energy from the capacitor banks to magnetic-field coils in either the REBA or Rehyd experimental cells. Each unit is covered with a safety-debris shield (not shown in the figure).

The capacitor banks are operated from a console located adjacent to the REBA/Rehyd control console. To insure proper voltage and current to the magnetic-field coil at the time of electronbeam injection, the capacitor bank can be made to fire the Marx generator with a selected, variable delay.

\section{Oil Heaters}

To alleviate the effects of cold oil which, at times, crystallizes or adheres to the diode rings and lucite barrier plate, an oil heater system was permanently installed on the north side nf the Marx tank. The system consists of two 8240-Btu electric boilers connected in series, a circulating pump, a temperature controller, and a thermometer, along with the necessary plumbing to circulate oil through the Marx tank and filters. After initial heating, the oil temperature is automatically maintained at 26 to $30^{\circ} \mathrm{C}$. 


\section{Operating Characteristics and Parameters}

\section{Performance Characteristics}

The primary goal of the Rehyd development program was to obtain a reliable, 5-cal/g, bremsstrahlung exposure capability with a beam energy of about $25 \mathrm{~kJ}$ applied over an area of $7 \mathrm{~cm}^{2}$. Actual performance characteristics were established at various stages in the development. Changes included improvements in the diode design and convertor assemblies and optimization of the external magnetic field. Applied analytical techniques along with test results on various system components are described in detail in a previous report ${ }^{1}$ and will not be repeated here. The Rehyd performance characteristics obtained with a Mod II diode configuration and advanced cunvertor assembly (see Figure 9) are given in Table 1. 'I'he magnetic cumpressiun 1atio wad $2: 1$.

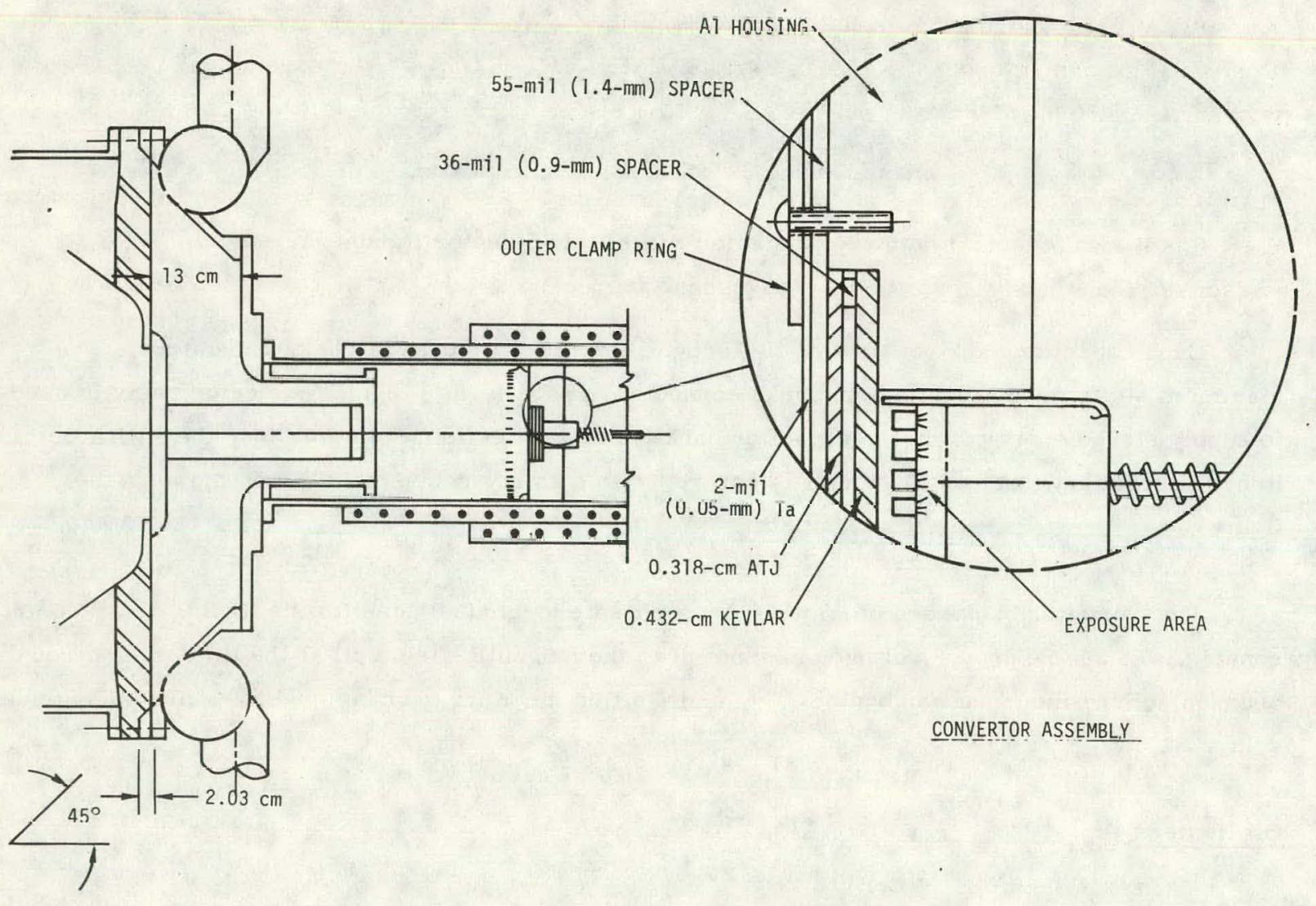

Figure 9. Diode Mod II and Convertor Assembly with Standoff and Gap for Rehyd 
TABLE I

Rehyd Performance Characteristics With Mod II Diode Configuration and Advanced Convertor Assembly

\begin{tabular}{lccccccc}
\hline $\begin{array}{l}\text { Diode } \\
\text { Design }\end{array}$ & $\begin{array}{c}\mathrm{V}_{\text {max }} \\
\text { (MV) }\end{array}$ & $\begin{array}{c}\mathrm{I} \\
\text { (MA) }\end{array}$ & $\begin{array}{c}\Delta \mathrm{t}_{\mathrm{p}} \\
(\mathrm{ns})\end{array}$ & $\begin{array}{c}\mathrm{E}_{\mathrm{B}} \\
(\mathrm{kJ})\end{array}$ & $\begin{array}{c}\text { Dose } \max \\
(\mathrm{cal} / \mathrm{g})\end{array}$ & $\begin{array}{c}\Delta \mathrm{t}_{\mathrm{brem}} \\
\text { (ns) }\end{array}$ & $\begin{array}{c}\text { Exposure } \\
\text { Area }\end{array}$ \\
\hline Mod II & 1.2 & 0.30 & 170 & $20-25$ & 7 & 90 & $9 \mathrm{~cm}^{2}$ \\
\hline
\end{tabular}

\section{Photon Energy Spectrum}

Monte Carlo calculation techniques were used to generate the bremsstrahlung energy spectrum (Figure 10) as determined from traces of diode current and voltage. For these calculations, the peak anode-cathode gap voltage was assumed to be $1.0 \mathrm{MV}$ and peak current was assumed to be $325 \mathrm{kA}$. As a low-resolution check on the spectral data, the ratio of dose (1-mil Au) to dose (LiF TLD-100) was calculated to be 15, which is in reasonably good agreement with the measured value of 13. Additional spectral data were obtained with filter-fluorescence measurements, ${ }^{6}$ and comparisons of these measured spectra with theoretical results are shown in Figures 11 and 12.

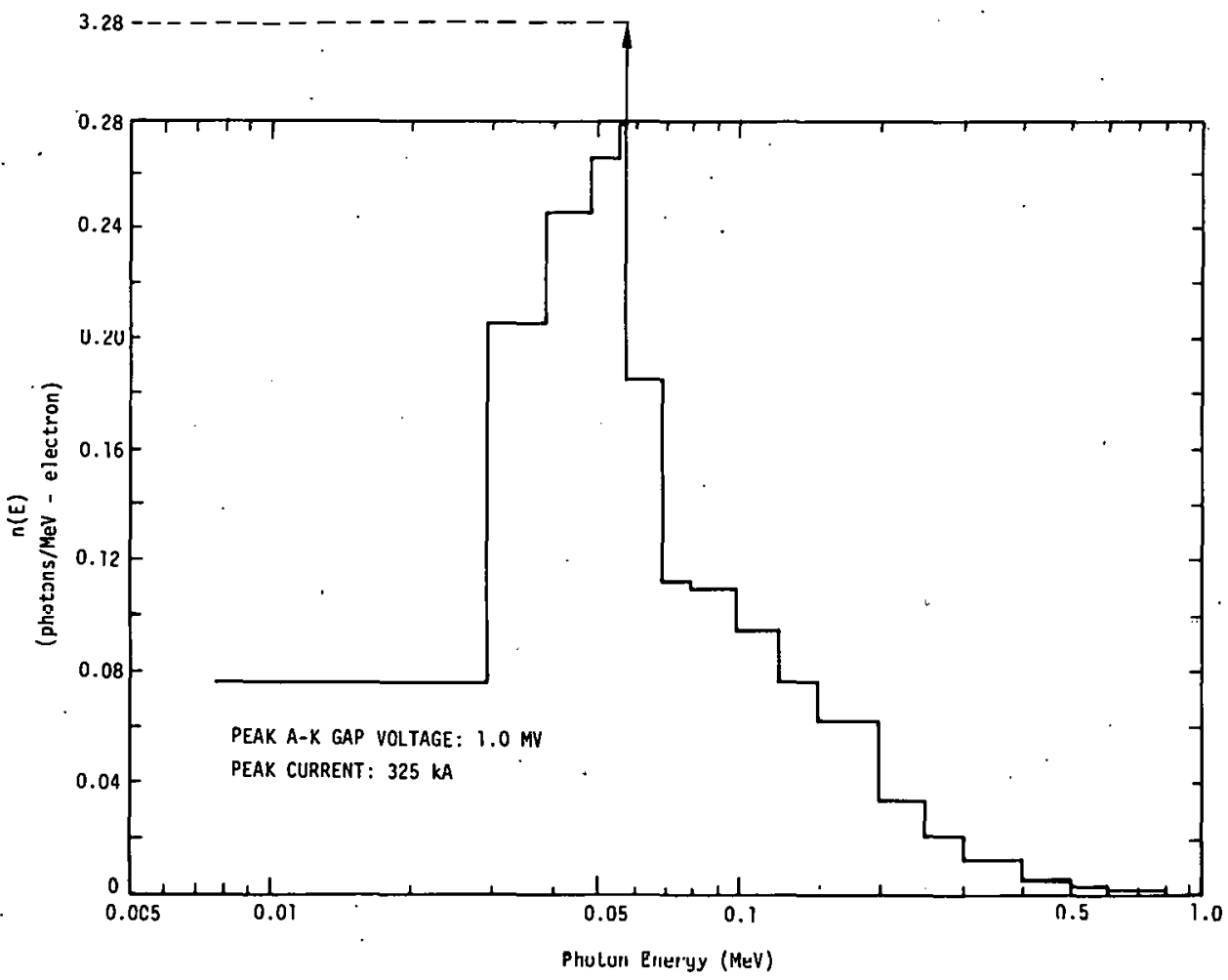

Figure 10. Calculated Rehyd Photon Energy Spectrum for Shot No. 282 


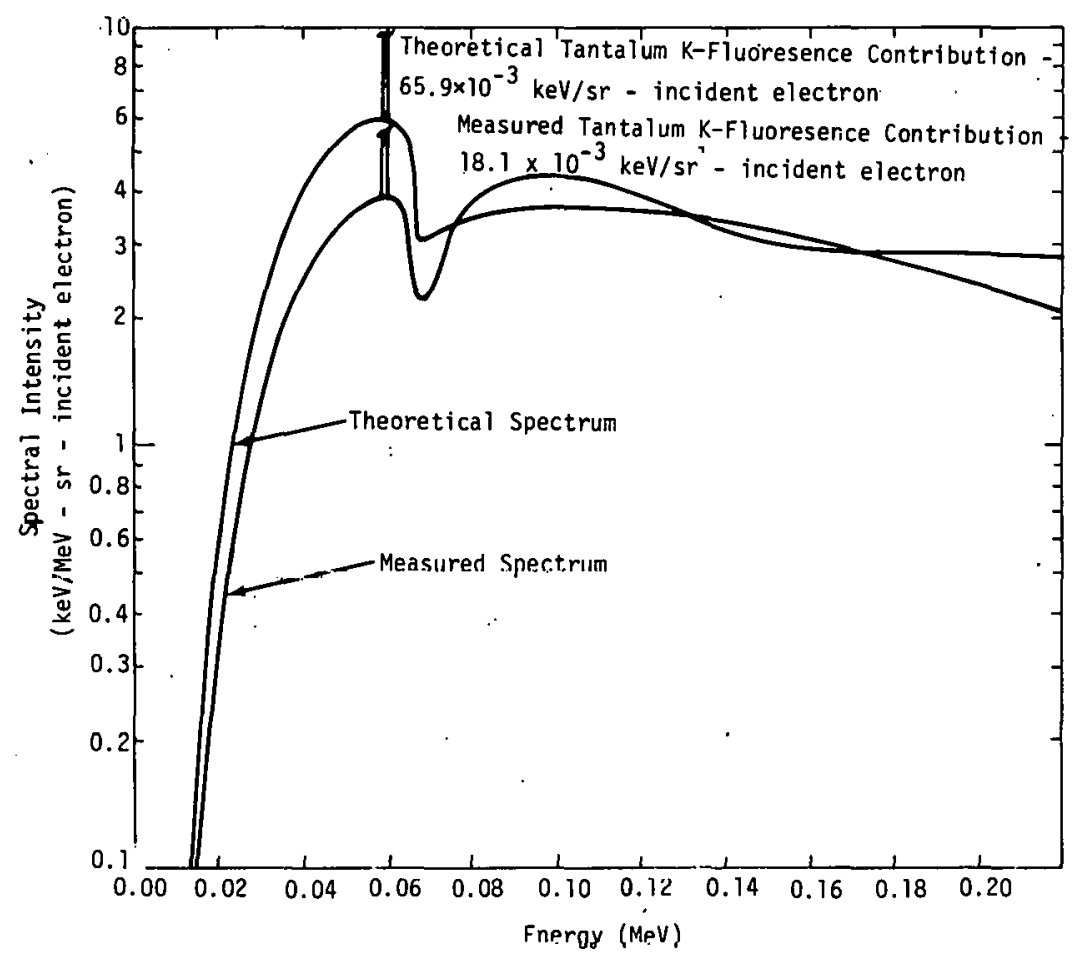

Figure 11. Rehyd X-Ray Spectra Along Forward-Directed Normal to Convertor for Energies Less Than 0.2 MeV (Normalized to $1.0 \mathrm{keV} / \mathrm{sr}$-elest.ron)

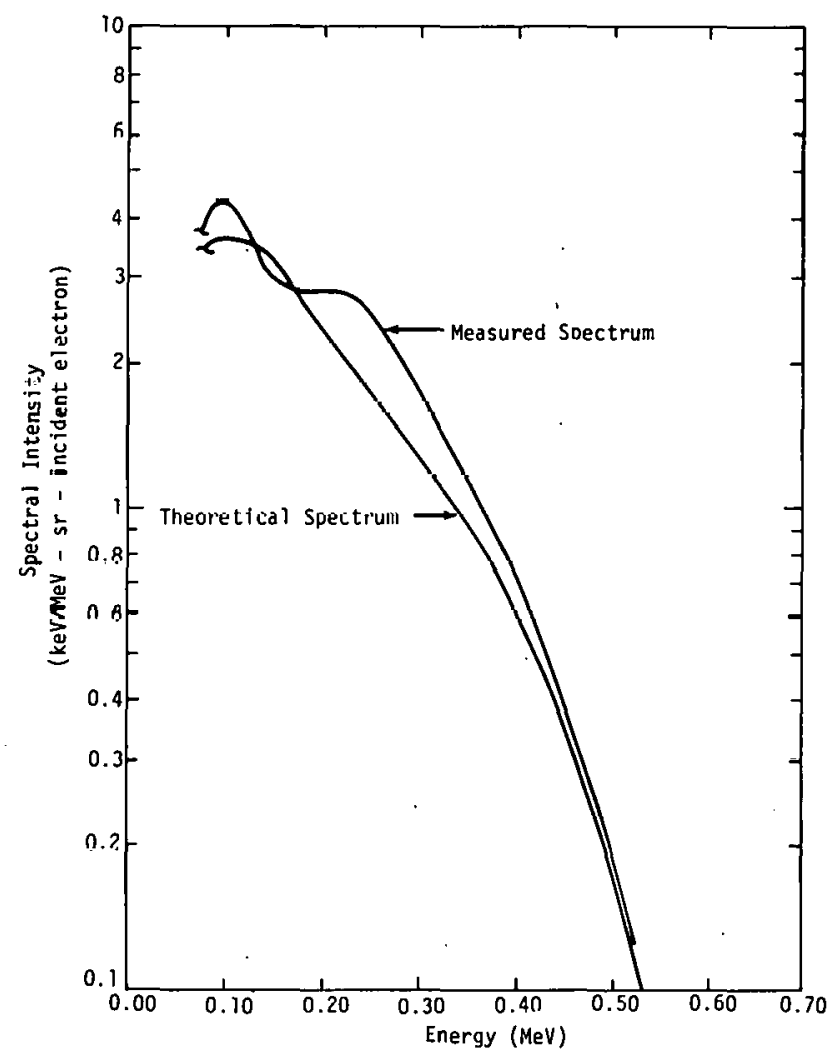

Figure 12. Rehyd X-Ray Spectra Along Forward-Directed Normal to Convertor for Energies Greater Than $0.1 \mathrm{MeV}$

(Normalized to $1.0 \mathrm{keV} / \mathrm{sr}$-electron) 


\section{Electrical Parameters}

Rehyd electrical parameters are similar to those for one line of HYDRA, and many experiments may be performed on either accelerator. Electrical parameters and other Rehyd specifications are outlined in the appendix.

Data Acquisition and Monitors

Diode Monitors

Permanent detectors are installed in the diode area to monitor current and voltage. Such detectors usually consist of $\mathrm{B}_{\theta}$ coils and capacitive voltage monitors. Data from an experiment are extracted through external diagnostic systems and collected in a shielded screen room or else transmitted to an instrumentation van.

Instrument Screen Rooms

At the time of the modification of the REBA facility, the existing screen room was relocated to the east end of the REBA Marx (see Figure 2). This has been recently expanded and affords screen-room access to both the Rehyd and REBA facilities. Another screen room (which contains a computer-access substation) is located in the low-bay office area of Building 6596 (not shown).

Instrumentation Van

The Rehyd facility is supported by an instrumentation van from Sandia Laboratories'. Simulation Instrumentation Division. An instrumentation cable boom $2.1 \mathrm{~m}$ in length is attached to the south wall of the test cell at a height of $2.1 \mathrm{~m}$ above the floor on a hinge which allows it to be swiveled to various positions. Cables are routed in shielded, ground-level troughs to the instrument van.

The van provides a multitude of data acquisition capabilities, including oscilloscopes, signal generators, power supplies, recorders, and transient digitizer systems. Data from the digitizer' system are received in the form of either hard-copy plots and/or digital data recorded on cassettes.

Safety

Both Rehyd and REBA experimental cells are equipped with "Machine Active" warnings and, in addition, both areas are monitored with closed-circuit television from the control console. The Rehyd Experimental Review Committee considers all tests that may be hazardous or that contain toxic materials. In such cases, modifications may be made to the Rehyd cell or special equipment may be utilized to insure personnel safety. 
$d$

\section{Summary}

Rehyd was first made available to experimenters in January 1975 and has been utilized in,a variety of experiments, including simulation tests, materials effects, and fusion experiments. 7 Approximately 1545 shots have been recorded through May 1977. No major modifications have been required except for changes in power levels or ventilation schemes for particular experiments.

The performance of Rehyd has been better than originally expected and, in most cases, the design operating parameters have been exceeded. As mentioned earlier, many Rehyd experiments are also compatible with single-line HYDRA operatluns dud, llelefüe, Reliyd has inereascd the capability to perform experiments utilizing a high-current, pulsed-beam source. 


\section{References}

1. L. D. Posey, P. B. Tollefsrud, H. N. Woodall, D. H. McDaniel, and R. E. Allred, "X-Ray Simulation Development, " Proceedings of Fifth Symposium on Nuclear Survivability of Propulsion and Ordnance Systems, held at the Stanford Research Institute, October 7-9, 1975.

2. T. H. Martin, "The Hydra Electron-Beam Generator," IEEE Trans, on Nucl. Sci., NS-20, No. 3, 289 (1973).

3. D. L. Johnson, REBA; A Pulsed Electron-Beam Generator, SC-DR-70 872, Sandia Laboratories, Albuquerque, NM, December 1970.

4. R: L. Schuch, REBA Experimenter's Manual, SAND77-0340, Sandia Laboratories, Albuquerque, NM, April 1977.

5. J. E. Boers, FFEARS, A Digital Computer Program for the Simulation of Laplace's Equation Including Dielectric Interfaces and Small Ungrounded Electrodes, SC-RR-71 0377, Sandia Laboratories, Albuquerque, NM, July 1971.

6. J. Hohlfelder, Measurements of the X-Ray Spectrum from the Rehyd Machine, SAND76-0426, Sandia Laboratories, Albuquerque, NM, August 1976.

7. "U. S. Electron Beam Tests Trigger Fusion, " Aviation Week, July 4, 1977, p. 22. 
Output

$\begin{array}{ll}\text { A-K } & 1.2 \mathrm{MV} \\ \text { Current } & 0.3 \mathrm{MA} \\ \text { Total Tube Impedance } & 3 \Omega \\ \text { Electrical Pulse Length } & 170 \mathrm{~ns} \\ \text { Beam Energy } & 35 \mathrm{~kJ} \text { max. } \\ \text { Number of Cathodes } & 1\end{array}$

\section{Line Characteristics}

Electrical Length

Outer Diameter

Inner Diameter

Nominal Impedance

Maximum Charge Voltage

Maximum Electrical Field in Coax

Maximum Electrical Field on Interface

Capacity

Equivalent Series Resistance

(1 $\mathrm{M} \Omega / \mathrm{cm}, \mathrm{H}_{2} \mathrm{O}$ )

Prepulse Level

Switch Inductance

Tube Inductance

Insulation

Stored Energy

Marx Generator

Capacitance per Stage

Number of Stages

Number of Spark Gaps

Charging Voltage

Total Energy Stored

Output Capacity
$170 \mathrm{~ns}$

1. $37 \mathrm{~m}$

$0.76 \mathrm{~m}$

$2 \Omega$

3. $0 . \mathrm{MV}$

-150 to $+85 \mathrm{kV} / \mathrm{cm}$

$100 \mathrm{kV} / \mathrm{cm}$

11. $2 \mathrm{nF}$

$700 \Omega$

$51.0 \mathrm{kV}$

$240 \mathrm{nH}$

$36-85 \mathrm{nH}$

$\mathrm{H}_{2} \mathrm{O}$

$60 \mathrm{~kJ}$

$0.5 \mu \mathrm{F}$

38

19

$100 \mathrm{kV} \max$.

$95 \mathrm{~kJ}$

$13,100 \mathrm{pF}$ 
Marx Generator (continued)

Inductance

Series Resistance

Parallel Resistance

Marx Lossless Output Voltage

Mod II Diode Characteristics

- Peak Diode Voltage

Peak Anode- Cathode Voltage

Peak Current

Current Risetime

Tube Impedance

'l'ube Inductance

Cathode Diameter

Total Cathode Area

\section{X-Ray Environment}

Dose/Pulse

Pulse Width

Electron-Beam Environment

Beam Energy

Peak Power

Pulse Width

Dose/ Pulse
$26 \mu \mathrm{H}$

$3 \Omega$

$1,000 \Omega$

$3.8 \mathrm{MV}$

1. $2 \mathrm{MV}$

1. $1 \mathrm{MV}$

$0.3 \mathrm{MA}$

40 ns

$3 \Omega$

$65 \mathrm{nH}$

$7.82 \mathrm{~cm}$

$45.6 \mathrm{~cm}^{2}$

$7 \mathrm{cal} / \mathrm{g}(1-\mathrm{mil} \mathrm{Au})$

120 - 140 ns (base-to-base)

$20-25 \mathrm{~kJ}$

$0.4 \mathrm{TW}$

$170 \mathrm{~ns}$ (base-to-base)

$1000 \mathrm{cal} / \mathrm{g}\left(20-\mathrm{cm}^{2}\right.$ graphite) 
DISTRIBUTION:

Lockheed Missiles and Space Co. Dept. 8585, Building 182

P. O. Box 504

Sunnyvale, CA 94088

Attn: P. Perry

Los Alamos Scientific Laboratory Group WX-1

P. O. Box 1663

Los Alamos, NM 87544

Attn: R. Dingus

Mission Research Corp. 5601 Domingo Road

P. O. Box 8693

Albuquerque, NM 87108

Attn: A. Chodorow

Ktech Corp.

911 Pennsylvania, NE

Albuquerque, NM 87110

Attn: D. V. Keller

1000 G. A. Fowler

1100 C. D. Broyles

1112 J. L. Benson

1116 J. D. Plimpton

1125 G. L. Ogle

1126 R. W. Donohoe

1126 S. M. Falacy

1126 M. E. Gilmer

2140 B. L. Gregory

2144 H. H. Sander

2300 J. C. King

2500 J. C. Crawford

2530 M. K. Parsons

2531 T. J. Young

3310 W. H. Kingsley

3311 D. R. Parker

3312 W. D. Burnett

3312 H. D. Abbott

4300 R. L. Peurifoy, Jr.

4310 C. C. Burks

4312 J. L. Duncan

4312 J. H. Barnum

4335 R. D. Christopher.

4336 S. L. Jeffers

4338 W. D. Ulrich

5000 A. Narath

5150 J. E. Schirber

5167 B. Mi. Butcher

5167 D. A. Benson

5167 A. L. Ouellette

5200 E. H. Beckner

5210 J. B. Gerardo

6212 R. A. Gerber

5214 E. D. Jones

6316 A. W. Johnson

5230 M. Cowan

5231 J. A. Halbleib

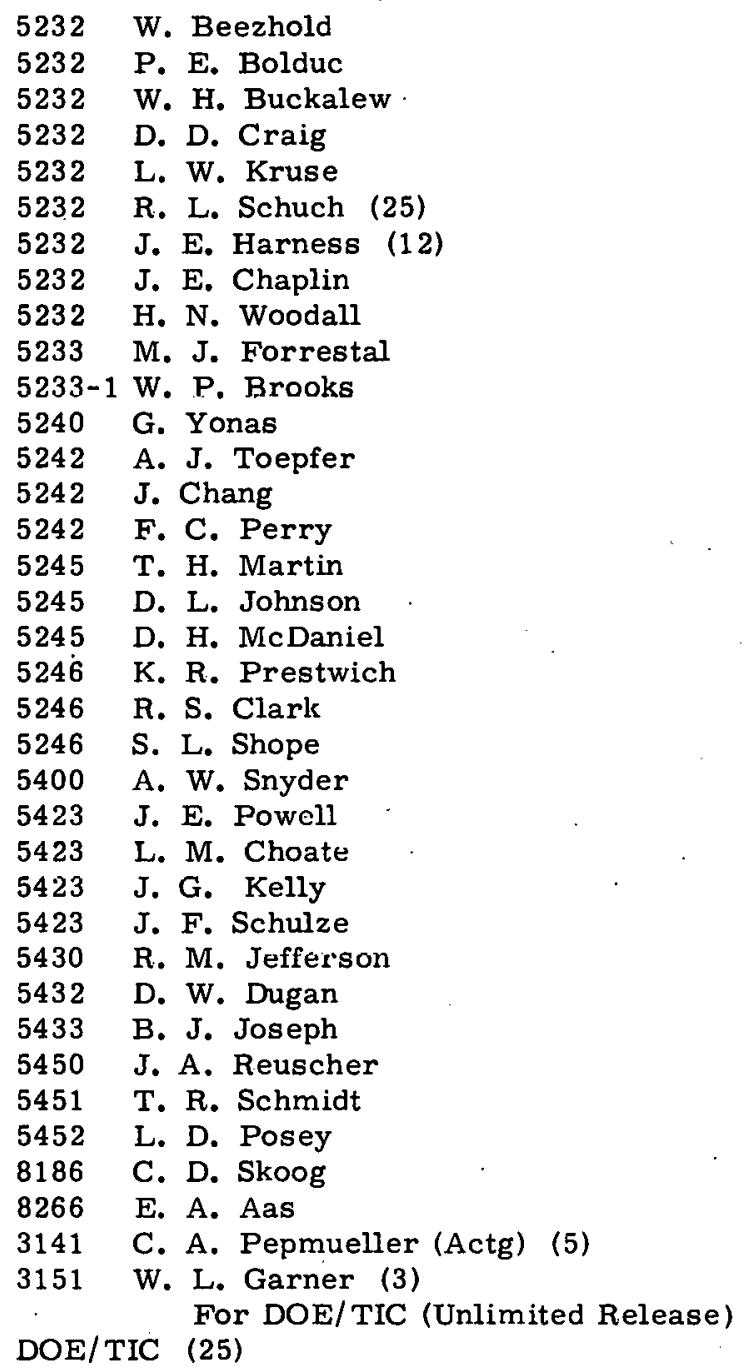

(R. P. Campbell, 3172-3) 